\title{
Focus on ROS1-Positive Non-Small Cell Lung Cancer (NSCLC): Crizotinib, Resistance Mechanisms and the Newer Generation of Targeted Therapies
}

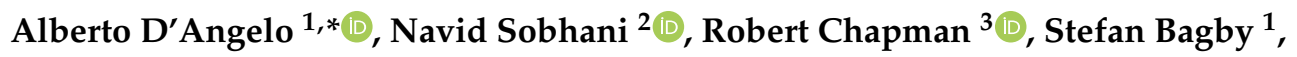 \\ Carlotta Bortoletti ${ }^{4}$, Mirko Traversini ${ }^{5}$, Katia Ferrari ${ }^{6}$, Luca Voltolini ${ }^{7}$, Jacob Darlow ${ }^{1}$ and \\ Giandomenico Roviello ${ }^{8}$ (D) \\ 1 Department of Biology and Biochemistry, University of Bath, Bath BA2 7AY, UK; bsssb@bath.ac.uk (S.B.); \\ jbd31@bath.ac.uk (J.D.) \\ 2 Section of Epidemiology and Population Science, Department of Medicine, Baylor College of Medicine, \\ Houston, TX 77030, USA; navidsobhani19@gmail.com \\ 3 University College London Hospitals NHS Foundation Trust, 235 Euston Rd, London NW1 2BU, UK; \\ robert.chapman2@nhs.net \\ 4 Department of Dermatology, University of Padova, via Vincenzo Gallucci 4, 35121 Padova, Italy; \\ bortoletti.carlotta@gmail.com \\ 5 Unità Operativa Anatomia Patologica, Ospedale Maggiore Carlo Alberto Pizzardi, AUSL Bologna, \\ Largo Bartolo Nigrisoli 2, 40100 Bologna, Italy; traversini.mirko@gmail.com \\ 6 Respiratory Medicine, Careggi University Hospital, 50139 Florence, Italy; katia3ferrari@gmail.com \\ 7 Thoracic Surgery Unit, Careggi University Hospital, Largo Brambilla, 1, 50134 Florence, Italy; \\ luca.voltolini@unifi.it \\ 8 Department of Health Sciences, Section of Clinical Pharmacology and Oncology, University of Florence, \\ Viale Pieraccini, 6, 50139 Florence, Italy; giandomenicoroviello@gmail.com \\ * Correspondence: ada43@bath.ac.uk
}

Received: 22 September 2020; Accepted: 5 November 2020; Published: 6 November 2020

Simple Summary: Genetic rearrangements of the ROS1 gene account for up to 2\% of NSCLC patients who sometimes develop brain metastasis, resulting in poor prognosis. This review discusses the tyrosine kinase inhibitor crizotinib plus updates and preliminary results with the newer generation of tyrosine kinase inhibitors, which have been specifically conceived to overcome crizotinib resistance, including brigatinib, cabozantinib, ceritinib, entrectinib, lorlatinib and repotrectinib. After introducing each agent's properties, we provide suggestions on the best approaches to identify resistance mechanisms at an early stage, and we speculate on the most appropriate second-line therapies for patients who reported disease progression following crizotinib administration.

Abstract: The treatment of patients affected by non-small cell lung cancer (NSCLC) has been revolutionised by the discovery of druggable mutations. ROS1 (c-ros oncogene) is one gene with druggable mutations in NSCLC. ROS1 is currently targeted by several specific tyrosine kinase inhibitors (TKIs), but only two of these, crizotinib and entrectinib, have received Food and Drug Administration (FDA) approval. Crizotinib is a low molecular weight, orally available TKI that inhibits ROS1, MET and ALK and is considered the gold standard first-line treatment with demonstrated significant activity for lung cancers harbouring ROS1 gene rearrangements. However, crizotinib resistance often occurs, making the treatment of ROS1-positive lung cancers more challenging. A great effort has been undertaken to identify a new generation or ROS1 inhibitors. In this review, we briefly introduce the biology and role of ROS1 in lung cancer and discuss the underlying acquired mechanisms of resistance to crizotinib and the promising new agents able to overcome resistance mechanisms and offer alternative efficient therapies. 
Keywords: lung cancer; solid tumours; crizotinib; toxicity; TKI inhibitors; resistance mechanisms; targeted therapies; ROS1; NSCLC

\section{Introduction}

Lung cancer is a leading cause of cancer mortality in both men and women worldwide, despite major recent therapeutic breakthroughs in the field [1]. Non-small cell lung cancer (NSCLC) accounts for the vast majority (85\%) of lung malignancies. NSCLCs can be divided by their histological subtypes such as squamous cell carcinoma, large cell carcinoma and adenocarcinoma, with the latter the most diagnosed histological subtype. Two out of three advanced NSCLC patients harbour driver genetic alterations, including KRAS, BRAF, EGFR, MET and ERBB2 mutations or ALK, ROS1, RET and NTRK genomic rearrangements [2]. Currently, the vast majority of these alterations are therapeutically targetable, with KRAS the most commonly altered gene in NSCLC (approximately 13\%) and currently being targeted in a phase I clinical trial with sotorasib, a low molecular weight, highly selective $\mathrm{KRAS}^{\mathrm{G} 12 \mathrm{C}}$ inhibitor [3]. The recent administration of TKIs as a first-line regimen for ALK-rearranged and EGFR-mutated NSCLC outperformed the platinum-base chemotherapy in terms of response rates, progression-free survival (PFS) and overall survival (OS) [4]. Malignancies harbouring ROS1 gene rearrangements can be targeted by TKIs. Crizotinib, a tyrosine kinase inhibitor of ALK, ROS1 and cMET, is the first agent to report clinical efficacy in this subgroup of patients according to preclinical, phase I, retrospective and prospective studies [5-7]. Unfortunately, following initial positive responses to crizotinib, a large number of ROS1-rearranged patients show progression of disease (sometimes with brain metastasis) due to the occurrence of resistance mechanisms, such as the bypass of signalling pathways and novel mutations affecting the kinase domains of ROS1 [8]. However, given the relatively long survival of ROS1-positive NSCLC patients, a more recent ROS1 inhibitor generation is currently under investigation, with an encouraging improvement in the control of central nervous system (CNS) metastasis and a demonstrated efficacy in both pretreated and naïve crizotinib patients [9].

Here we review the current research involving ROS1-rearranged NSCLC patients, including ROS1 discovery, diagnostics, mechanisms exerted by malignant cells to evade inhibition and strategies to overcome acquired resistance. In addition, we focus on clinical efforts to target altered-ROS1 with standard regimens (crizotinib) and the more recent generation of ROS1 TKIs.

\section{ROS1 Discovery and Signalling Pathway}

ROS proto-oncogene 1 (ROS1), encoded by ROS1 gene located at chromosome 6q22.1, belongs to the subfamily of tyrosine kinase insulin receptors and was first identified in 1986 during research involving the chicken sarcoma RNA UR2 tumour virus [10]. The physiological role of ROS1 is still controversial; its expression has been observed mainly in lung tissue, followed by the cervix and colon. Tyrosine kinase insulin receptors conceivably play a key role in embryonic development [11]. ROS1 protein shows substantial homology to ALK (both belong to insulin receptor superfamily), particularly within the ATP binding site (84\% homology) and the kinase domains (64\% homology) [5,12]. Genomic alteration of ROS1 is well known and normally leads to gene fusion with several fusion partners (Table 1) [2,5,11,13-23]; the resulting fusion proteins are robust oncogenic drivers [24]. As a consequence, ROS1 kinase activity is constitutively activated, leading to increased cell proliferation, survival and migration due to the upregulation of JAK/STAT, PI3K/AKT and MAPK/ERK signalling pathways [11]. ROS1 has shown tumorigenic potential in vitro and in vivo, with glioblastoma the first human cancer shown to harbour ROS1 rearrangements [10]. ROS1 fusions have subsequently been observed in other malignancies including NSCLC [13], melanoma [19] and occasionally cholangiocarcinoma [25], angiosarcoma [26], ovarian [27], gastric [28] and colorectal cancer [29]. ROS1 alterations can neither be inherited nor acquired as genetic alteration [30]. 
Table 1. Main ROS1 fusion partners in non-small cell lung cancer (NSCLC).

\begin{tabular}{|c|c|c|c|c|c|}
\hline No & Gene & Alias & Description & $\begin{array}{l}\text { Estimated Frequency in } \\
\text { NSCLC }\end{array}$ & Reference \\
\hline 1 & CD74 & & Cluster of differentiation 74 & $32-42 \%$ & [13] \\
\hline 2 & SLC34A2 & & Solute carrier family 34 member 2 gene & $12-18 \%$ & [13] \\
\hline 3 & $E Z R$ & & Ezrin gene & $6-15 \%$ & [2] \\
\hline 4 & TMP3 & & Tropomyosin 3 gene & $3-15 \%$ & [2] \\
\hline 5 & SDC4 & & Syndecan 4 gene & $7-11 \%$ & [2] \\
\hline 6 & FIG & GOPC & Fused in Glioblastoma & $2-3 \%$ & [11] \\
\hline 7 & TMEM106B & & Transmembrane protein 106B & $1 \%$ & [11] \\
\hline 8 & CCDC6 & & Coiled-coil domain containing 6 gene & $1 \%$ & [14] \\
\hline 9 & LIMA1 & EPLIN & LIM domain and actin-binding 1 gene & $1 \%$ & [5] \\
\hline 10 & WNK1 & & Lysine deficient protein kinase 1 & $1 \%$ & [20] \\
\hline 11 & LRIG3 & & $\begin{array}{l}\text { Leucine-rich repeats and } \\
\text { immunoglobulin-like domains } 3 \text { gene }\end{array}$ & $1 \%$ & [2] \\
\hline 12 & TDP52L1 & & Tumour protein D52 like 1 gene & $1 \%$ & [11] \\
\hline 13 & CLTC & & Clathrin heavy chain gene & $1 \%$ & [16] \\
\hline 14 & MSN & & Moesin gene & $1 \%$ & [5] \\
\hline 15 & KDELR2 & $\begin{array}{c}E L P-1 \\
E R D 2.2\end{array}$ & $\begin{array}{l}\text { Endoplasmic reticulum protein retention } \\
\text { receptor } 2 \text { gene }\end{array}$ & $1 \%$ & [14] \\
\hline 16 & MYO5C & & Myosin VA (heavy chain 12, myoxin) & $1 \%$ & [19] \\
\hline 17 & TFG & & TRK-fused gene & $1 \%$ & [23] \\
\hline 18 & RBPMS & & RNA-binding protein with multiple splicing & $1 \%$ & [21] \\
\hline
\end{tabular}

\section{ROS1 in Lung Cancer and Brain Metastasis}

First described in 2007 [13], ROS1 rearrangements account for 1-2\% of NSCLC patients with an estimated 10,000-15,000 new cases every year worldwide (Table 1) [24,30]. Patients are often light smokers or non-smokers, and tend to be young. Adenocarcinoma is the most common histological subtype identified, but large-cell and squamous histology have also been reported [16,31]. ROS1-positive cancers show overlapping clinical features with ALK-rearranged NSCLC, although genetic rearrangements in ROS1, EGFR and ALK tend to be mutually exclusive [32]. Additionally, some ROS1-positive cancers demonstrate a second driver mutation, mainly KRAS and EGFR, after initial treatment with a TKI $[16,33,34]$. In clinical practice, ROS1-positive patients responded better to chemotherapy (CT) than NSCLC patients harbouring other driver mutations, with an estimated $60 \%$ objective response rate (ORR), 89.5\% disease control rate (DCR) and a 7 month PFS. The better response described is likely due to the sensitivity of ROS1-positive cancers to pemetrexed (Alimta) [14,35-38]. It has been speculated that this significant pemetrexed susceptibility might arise from the limited number of thymidylate synthetase (TS) transcripts in ROS1-positive patients [39-42]. Additionally, the response of ROS1-positive cancers to immunotherapy appears to be infrequent [43]. Furthermore, receptor tyrosine kinases (RTKs) found in ROS1-positive cancers are druggable targets and TKIs (such as crizotinib) therefore emerged as promising agents for the treatment of these cancers [8]. TKIs do not target fast-growing cells (as CT agents normally do), but only cells harbouring specific genomic alterations, and as a result, they lead to fewer side effects than CT agents. However, the development of resistance mechanisms to TKIs can be expected $[5,30]$.

\section{Brain Metastasis}

Metastases affecting the CNS are commonly observed in patients with lung cancer and ROS1-positive cancer patients are no exception. One study observed that approximately $40 \%$ of stage IV ROS1-positive lung cancer patients were diagnosed with brain metastasis [44]. Crizotinib is not the preferred agent for patients with brain metastasis due to its inability to penetrate the blood-brain barrier (BBB) [45]. Newer TKIs including repotrecninib, ceritinib, lorlatinib and entrectinib 
have been developed to penetrate the BBB. Entrectinib is the only agent approved by the FDA for NSCLC patients harbouring ROS1 alterations and is currently the preferred agent in those with brain metastasis $[46,47]$. Despite the encouraging results with entrectinib, radiation therapy is the preferred technique to treat brain metastasis; ROS1-rearranged cancers have shown significant sensitivity to this approach $[8,48]$. When multiple brain metastases are diagnosed, whole-brain radiation is the common approach. Alternatively, when fewer lesions are observed (three or four), stereotactic radiation, which includes gammaknife, cyberknife and linear accelerator (LINAC)-based radiotherapy approaches, is preferred; this results in fewer side effects and better control of potential in situ relapse when coupled with whole brain irradiation [49-52]. The full list of current clinical trials using TKI against ROS1-rearranged lung cancer is reported in Table 2.

Table 2. Ongoing clinical trials using TKI against ROS1-rearranged lung cancer.

\begin{tabular}{|c|c|c|c|c|c|c|}
\hline $\begin{array}{l}\text { Clinical Trial } \\
\text { Identifier }\end{array}$ & Study Design & Intervention/s & Setting & Primary Endpoint & Phase & Status \\
\hline NCT03399487 & $\begin{array}{c}\text { 46 Participants, } \\
\text { Single group assignment, } \\
\text { Non-Randomized, Open label }\end{array}$ & LDK378 (Ceritinib) & Second line & ORR & 2 & Recruiting \\
\hline NCT03972189 & $\begin{array}{c}111 \text { Participants, } \\
\text { Single group assignment, } \\
\text { Non-Randomized, Open label }\end{array}$ & TQ-B3101 & Second line & ORR & 2 & Recruiting \\
\hline NCT02927340 & $\begin{array}{c}30 \text { Participants, } \\
\text { Single group assignment, } \\
\text { Non-Randomized, Open label }\end{array}$ & Lorlatinib & $\begin{array}{l}\text { First or later } \\
\text { line }\end{array}$ & DCR & 2 & Recruiting \\
\hline NCT01639508 & $\begin{array}{c}68 \text { Participants, } \\
\text { Single group assignment, } \\
\text { Non-Randomized, Open label }\end{array}$ & Cabozantinib & Second line & ORR & 2 & Recruiting \\
\hline NCT01970865 & $\begin{array}{l}334 \text { Participants, Non-Randomized, } \\
\text { Open label }\end{array}$ & $\begin{array}{l}\text { PF-06463922 } \\
\text { Crizotinib }\end{array}$ & $\begin{array}{l}\text { First or later } \\
\text { line }\end{array}$ & $\begin{array}{l}\text { DLT (phase 1) } \\
\text { OR (phase 2) }\end{array}$ & 2 & $\begin{array}{l}\text { Active, not } \\
\text { recruiting }\end{array}$ \\
\hline NCT04302025 & $\begin{array}{c}60 \text { Participants, } \\
\text { Single group assignment, } \\
\text { Non-Randomized, Open label }\end{array}$ & $\begin{array}{c}\text { Alectinib } \\
\text { Entrectinib } \\
\text { Vemurafenib } \\
\text { Cobimetinib }\end{array}$ & $\begin{array}{l}\text { Second or } \\
\text { later line }\end{array}$ & MPR & 2 & $\begin{array}{l}\text { Not yet } \\
\text { recruiting }\end{array}$ \\
\hline NCT04084717 & $\begin{array}{c}50 \text { Participants, } \\
\text { Parallel assignment, } \\
\text { Non-Randomized, Open label }\end{array}$ & Crizotinib & Second line & RR & 2 & $\begin{array}{l}\text { Not yet } \\
\text { recruiting }\end{array}$ \\
\hline NCT03088930 & $\begin{array}{c}18 \text { Participants, } \\
\text { Single group assignment, } \\
\text { Non-Randomized, Open label }\end{array}$ & Crizotinib & Second line & $\mathrm{RR}$ & 2 & Recruiting \\
\hline NCT03087448 & $\begin{array}{c}69 \text { Participants, } \\
\text { Single group assignment, } \\
\text { Non-Randomized, Open label }\end{array}$ & $\begin{array}{l}\text { Ceritinib (Phase 1) } \\
\text { Trametinib (Phase 2) }\end{array}$ & $\begin{array}{l}\text { Second or } \\
\text { later line }\end{array}$ & MTD & $1-2$ & Recruiting \\
\hline NCT02183870 & $\begin{array}{c}30 \text { Participants, } \\
\text { Single group assignment, } \\
\text { Non-Randomized, Open label }\end{array}$ & Crizotinib & $\begin{array}{l}\text { Any prior } \\
\text { treatment }\end{array}$ & ORR & 2 & $\begin{array}{l}\text { Active, not } \\
\text { recruiting }\end{array}$ \\
\hline NCT01964157 & $\begin{array}{l}32 \text { Participants } \\
\text { Single group assignment } \\
\text { Non-randomized } \\
\text { Open label }\end{array}$ & LDK378 & $\begin{array}{l}\text { Second or } \\
\text { later line }\end{array}$ & ORR & 2 & Recruiting \\
\hline NCT04292119 & $\begin{array}{l}96 \text { Participants } \\
\text { Randomised } \\
\text { Parallel Assignment } \\
\text { Open label }\end{array}$ & $\begin{array}{l}\text { Lorlatinib, } \\
\text { Binimetinib, } \\
\text { Crizotinib }\end{array}$ & $\begin{array}{l}\text { Any prior } \\
\text { treatment }\end{array}$ & MTD, OR & $1-2$ & Recruiting \\
\hline NCT03608007 & $\begin{array}{l}69 \text { Participants } \\
\text { Single group assignment } \\
\text { Non-randomised } \\
\text { Open label }\end{array}$ & $\begin{array}{l}\text { X-396 Capsule } \\
\text { (Ensartinib) }\end{array}$ & Second line & OR & 2 & Recruiting \\
\hline NCT03718117 & $\begin{array}{l}70 \text { Participants } \\
\text { Cohort, Prospective }\end{array}$ & Crizotinib & $\begin{array}{l}\text { Any prior } \\
\text { treatment }\end{array}$ & Demographics & I & $\begin{array}{l}\text { Active, not } \\
\text { recruiting }\end{array}$ \\
\hline NCT04005144 & $\begin{array}{c}18 \text { Participants } \\
\text { Non-randomized } \\
\text { Single group assignment } \\
\text { Open label }\end{array}$ & $\begin{array}{l}\text { Brigatinib + } \\
\text { Binimetinib }\end{array}$ & $\begin{array}{l}\text { Second-line } \\
\text { or later }\end{array}$ & AE, DLT & 1 & Recruiting \\
\hline NCT02568267 & $\begin{array}{l}300 \text { Participants } \\
\text { Non-randomised } \\
\text { Parallel Assignment } \\
\text { Open label }\end{array}$ & Entrectinib & $\begin{array}{l}\text { Any prior } \\
\text { treatment }\end{array}$ & OR & 2 & Recruiting \\
\hline
\end{tabular}




\section{ROS1 Rearrangement Diagnosis}

ROS1-positive patients account for $1-2 \%$ of all lung cancer diagnoses, but the clinicopathological features alone are not robust enough for their detection. As a result, different techniques are employed to identify ROS1 rearrangements, including immunohistochemistry (IHC), fluorescence in-situ hybridisation (FISH), reverse transcriptase-polymerase chain reaction (RT-PCR) and next generation sequencing (NGS) (Table 3) [53]. Immunohistochemistry is considered an efficient tool to diagnose ROS1 rearrangements. IHC has the benefit of low cost, high sensitivity (ranging from $90 \%$ to $100 \%$ ), low operator requirements and shorter turnaround times when compared to FISH [50,54-57]. However, subjective evaluation, specificity and sensitivity of antibodies and tissue fixation might negatively influence results [58].

Table 3. Techniques for the detection of ROS1 rearrangements.

\begin{tabular}{|c|c|c|}
\hline Technique & Advantages & Disadvantages \\
\hline IHC & $\begin{array}{c}\text { High sensitivity } \\
\text { Economic } \\
\text { Easy to use } \\
\text { Short turnaround } \\
\text { Low number of cells required } \\
\text { Employed on conventional AFC }\end{array}$ & $\begin{array}{c}\text { Subjective evaluation } \\
\text { Tissue fixation procedure } \\
\text { Antibody chemical properties }\end{array}$ \\
\hline FISH & $\begin{array}{l}\text { Long time trustworthiness } \\
\text { Reliability } \\
\text { "Gold standard" tool }\end{array}$ & $\begin{array}{l}\text { Moderately expansive } \\
\text { Difficult to use } \\
\text { Labour intense } \\
\text { False-negative results }\end{array}$ \\
\hline RT-PCR & $\begin{array}{c}\text { Good specificity } \\
\text { Good sensitivity } \\
\text { Low amount of starting material }\end{array}$ & $\begin{array}{c}\text { FFPE samples only } \\
\text { Error-prone } \\
\text { More validation required } \\
\text { Good quality of starting material }\end{array}$ \\
\hline NGS & $\begin{array}{l}\text { Detection of novel fusions } \\
\text { Parallel identification } \\
\text { FFPE or biopsy specimen }\end{array}$ & $\begin{array}{l}\text { More validation required } \\
\text { Turnaround time } \\
\text { Specimen depletion }\end{array}$ \\
\hline
\end{tabular}

IHC: Immunohistochemistry; FISH: Fluorescent in-situ hybridization; PCR: polymerase chain reaction; NGS: next-generation sequencing; AFC: alcohol-fixed cytology; FFPE: formalin-fixed and formalin-embedded.

Fluorescence in-situ hybridisation has traditionally been considered the "gold standard" technique for the detection of ROS1 gene fusions, mainly due to the use of identical tests for ALK rearrangements $[15,50,59]$. In FISH, the specimen is deemed "positive" when more than $15 \%$ of evaluated cells, or more than 50 malignant cells [60], show single $3^{\prime}$ (centromeric) or split $3^{\prime}$ and $5^{\prime}$ (telomeric) signal $[55,56]$. FISH is considered technically challenging, moderately expensive, labour intensive and prone to false-negative results [58].

Reverse transcriptase-polymerase chain reaction (RT-PCR) requires an RNA sample to be converted to complementary DNA (cDNA) first and then amplified, allowing specific identification of gene fusion partners. RT-PCR sensitivity and specificity are good, but it relies on RNA obtained from formalin-fixed and paraffin-embedded (FFPE) samples, which might limit its use in routine lab work [61]. An emerging test is currently provided by NanoString, which gives $100 \%$ sensitivity and specificity for ROS1 rearrangement identification [62]. However, this PCR method can introduce sequence artefacts leading to potential errors when processing highly fragmented or short nucleic fragments [61]. Lastly, next generation sequencing (NGS) enables the identification, in parallel, of known or novel ROS1 fusion alterations (and other oncogenic mutations) using either DNA or RNA as a starting material [63]. Moreover, DNA-based NGS can also detect fusion gene rearrangements with short intron regions, though it might struggle with long intron regions, and often fusion genes might differ from the RNA-messenger fusions [64]. It is highly possible that NGS will become the gold standard test for the identification of ROS1 fusion genes in the foreseeable future, due to its 
capability for massively parallel sequence testing and the detection of both known and novel gene rearrangements. Nonetheless, exhaustion of specimen and extended turnaround time might hamper its introduction in routine clinical practice [4]. The full list of the advantages and disadvantages of each technique is reported in Table 2.

\section{Targeting the ROS1 Oncogene with Crizotinib}

Crizotinib (Xalkori), originally formulated as an antihepatocyte growth factor receptor (MET) agent, is a TKI against several targets including ROS1, anaplastic lymphoma kinase (ALK) and MET [31,65]. Crizotinib inhibits ATP-dependent cellular functions by binding to respective protein kinase domains leading to potent ROS1, MET and ALK suppression [11]. Its efficacy was firstly reported in a ROS1-rearranged cell line when the inhibition of ROS1 phosphorylation led to a robust dose-dependent (IC50 of $60 \mathrm{nM}$ ) cell apoptosis; IC50 of $8 \mathrm{nM}$ and 40-60 nM against MET and ALK respectively [24,65-67]. However, it was only in 2012 that the first report on the use of crizotinib in the treatment of ROS1-rearranged lung cancers was published. A young, non-smoking male diagnosed with $A L K$ and EGFR-negative multifocal NSCLC showed disease progression after first-line erlotinib and developed genomic alteration in ROS1. The patient was treated with $250 \mathrm{mg}$ crizotinib twice per day, which led to a significant improvement in patient-reported symptoms within 7 days and dramatic shrinkage of malignant lesions at imaging within 8 weeks [31].

In the phase I PROFILE 1001 clinical trial, 50 patients with ROS1-rearranged NSCLC were included (as an expansion cohort) alongside ALK-rearranged advance NCLSC patients, all of whom were treated with crizotinib [5,68]. ROS1-positive patients reported a DCR of 90\%, a median PFS of 19.2 months, an ORR of $72 \%$ and an OS rate of approximately $85 \%$ at 12 months. 5 patients (10\%) showed treatment-related adverse events (AEs) including vomiting, nausea, constipation, diarrhoea, fatigue, visual impairment and dizziness; the vast majority evaluated as clinically manageable with only $4 \%$ evaluated as grade 3 of 4 , and no grade 5 AEs were observed [5]. Based on this study, in 2016 the FDA and EMA approved the use of crizotinib for advanced ROS1-rearranged NSCLC patients [69]. Subsequently, in 2019 the updated results of the study showed a final median PFS and OS of 19.3 months and 51.4 months respectively [68]. Following these results, prospective and retrospective studies were carried out to confirm crizotinib efficacy in ROS1-rearranged NSCLC. The EUROS1 Cohort study retrospectively evaluated crizotinib efficacy in 32 ROS1-positive patients and reported a disease control rate of nearly $87 \%$, a PFS of $44 \%$ at 12 months and, remarkably, 5 patients achieved a complete response [14]. In the Acsè prospective phase II trial, the 39 ROS1-positive NSCLC patients included showed a DCR of $89 \%$ and an overall ORR of $54 \%$ with $43 \%$ of patients evaluated to have no-progression of disease after 12 months [70]. Among 34 patients recruited in the EUCROSS phase II trial, an ORR of approximately $70 \%$ was observed [71]. The Asiatic side, a prospective study recruiting 127 patients, reported a DCR of $89 \%$ at 8 weeks, an ORR of $72 \%$, a median PFS and median OS of 15.9 and 32 months respectively, with 14 patients (11\%) achieving a complete response [6]. The overlapping clinical responses between European and Asian studies demonstrated the efficacy of crizotinib across different ethnicities.

\section{Mechanisms of Resistance to Crizotinib}

The development of crizotinib resistance in previously sensitive cancer cells is a key cause of treatment failure and invariably leads to disease progression. Proposed mechanisms of crizotinib resistance in cancer cells can be broadly split into either the genetic alteration of the drug target or the activation of other signalling pathways (e.g., bypass signalling; Figure 1) [72,73]. Studies suggest that point mutations within the ROS1 kinase domain can lead to significant alterations of the drug target resulting in acquired resistance to crizotinib; such mutations decrease the potency of kinase inhibition [73,74]. Many examples of point mutations in the ROS1 gene have been identified in crizotinib-resistant forms of NSCLC (Table 4). A ROS1 D2033N mutation was detected in a patient with disease progression after a previous crizotinib-sensitive NSCLC CD74-ROS1 fusion diagnosis [75]. 
The D2033N mutation generates an aspartic acid to asparagine substitution at the kinase hinge region of ROS1 (within the ATP-binding site), leading to strong crizotinib resistance in vitro [30,75]. Similarly, G2032R is a mutation in the ROS1 kinase domain, which has been detected in samples of malignant cells post-crizotinib treatment, with the mutation not present at the pretreatment stage [76]. G2032R is thought to be the most common driving mutation of crizotinib resistance and the most difficult to treat from a pharmacological point of view [8,77]. Other examples include L2026M, which induces resistance to crizotinib by altering the gatekeeper position of the inhibitor binding pocket of ROS1 [73,78]. Additionally, L2155S is thought to confer crizotinib resistance via protein malfunction, whereas the S1986F/Y substitution within the kinase domain leads to an obstruction of the key site for activation, thereby increasing kinase activity [79].

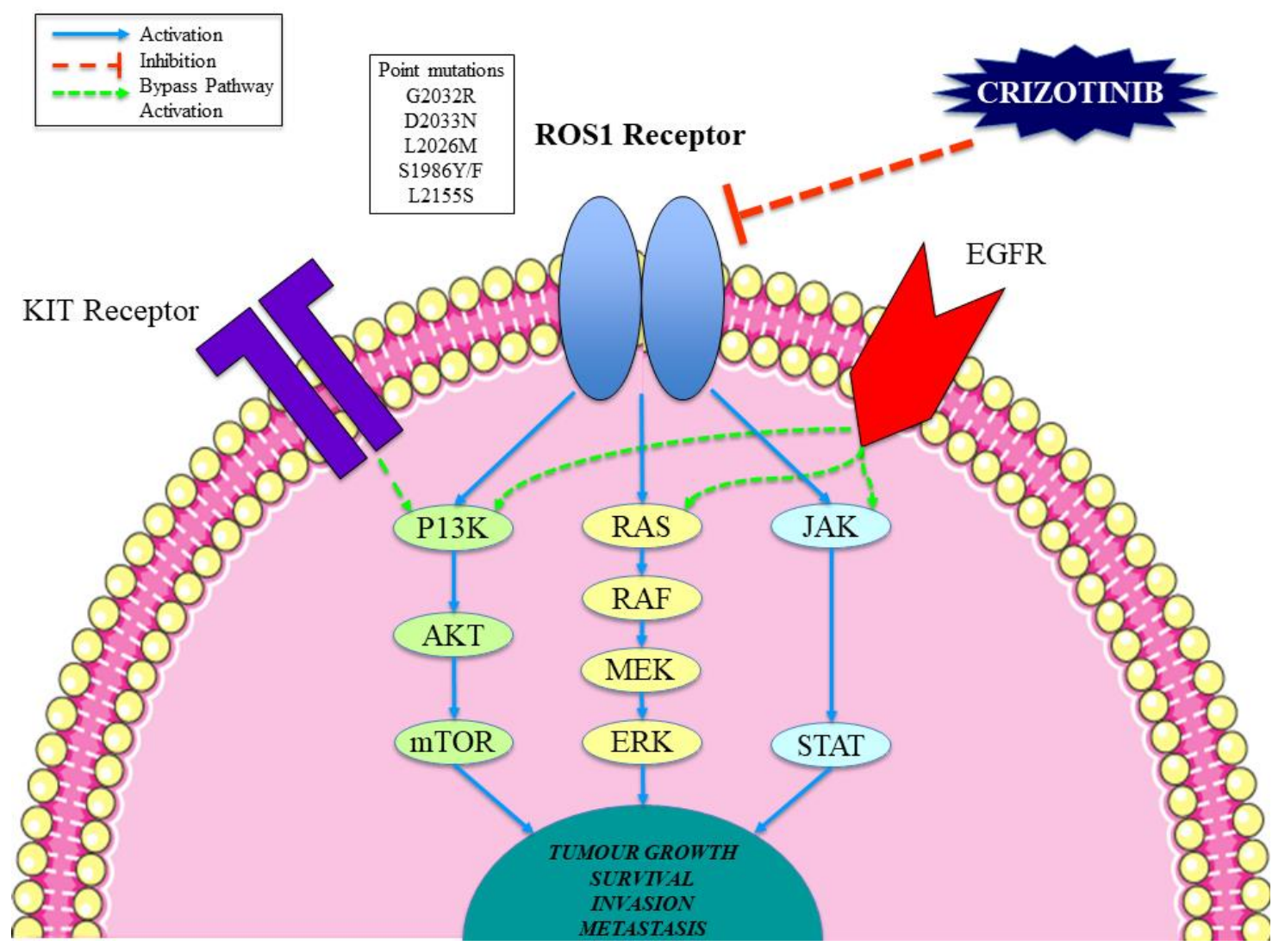

Figure 1. Molecular mechanisms of crizotinib in ROS1-rearranged lung cancer patients.

Table 4. ROS1 mutations conferring resistance to crizotinib and mechanism of action.

\begin{tabular}{cccc}
\hline Mutation & ROS1 fusion & Location & Mechanism \\
\hline D2033N & CD74-ROS1 & Kinase hinge & $\begin{array}{c}\text { Modification of } \\
\text { electrostatic forces }\end{array}$ \\
\hline G2032R & CD74-ROS1 & Kinase hinge & Steric interference \\
\hline L2026M & CD74-ROS1 & Inhibitor binding site & $\begin{array}{c}\text { Hindrance of drug } \\
\text { binding }\end{array}$ \\
\hline L2155S & SLC34A2-ROS1 & Not known & Protein malfunction \\
\hline S1986F/Y & EZR-ROS1 & Not known & $\begin{array}{c}\text { Obstruction of the active } \\
\text { site of the enzyme }\end{array}$ \\
\hline
\end{tabular}

Furthermore, the activation of bypass signalling as a method of crizotinib resistance in ROS1 cancer cells has been described in various studies and identified in approximately $45 \%$ of crizotinib-resistant 
ROS1-rearranged NSCLC malignancies (Figure 1) [80,81]. The activation of the EGFR pathway has been shown to confer crizotinib resistance by reducing the dependence on ROS1 activity and increasing dependence on EGFR activity $[79,82,83]$. This signalling switch might lead ROS1-rearranged NSCLCs to be targeted in the future with EGFR inhibitors such as erlotinib and gefitinib [8]. Similarly, it has been shown that KIT pathway activation can lead to crizotinib resistance as well as promoting autophosphorylation and cell proliferation in vitro [72,81]. Consequently, it might be thought that the addition of a KIT inhibitor such as ponatinib might be beneficial in such cases. Lastly, upregulation of MAPK signalling plus the amplification of TP53 and HER2 have been reported in crizotinib-resistant cells and might play a key role in bypass mechanisms $[45,80]$.

\section{A New Generation of TKIs to Overcome Crizotinib Resistance and Combination Regimens}

A novel and more potent generation of TKIs against genetic ROS1-alterations, which confer resistance to crizotinib, are currently under clinical investigation. These include brigatinib, cabozantinib, ceritinib, entrectinib, lorlatinib and repotrectinib. These newer agents have demonstrated clinical efficacy against ROS1-positive NSCLCs and more robust CNS penetration [8,76], and may be effective in the case of resistance resulting from a novel ROS1 mutation [4]. Nonetheless, when the resistance results from the activation of bypass mechanisms (i.e., EGFR or KIT pathways), inhibition is still possible by targeting both ROS1 and the bypass pathway with the use of a combination therapy such as crizotinib plus an EGFR/KIT inhibitor [72].

\subsection{Brigatinib}

The ALK inhibitor brigatinib has demonstrated clinical activity against different mutations correlated with resistance to crizotinib, including ROS1 gene rearrangements [84,85]. In three ROS1 patients, recruited as an expansion arm of a larger phase II study that included 137 NSCLC patients, two $(66 \%)$ had an objective treatment response. Moreover, one patient was crizotinib-naïve and reported partial response while the other patient was crizotinib pretreated and reported stable disease. Overall, brigatinib toxicity was reported to be manageable with increased lipase (9\%) as primary grade 3 or $4 \mathrm{AE}$, while serious treatment-related AEs such as dyspnoea and pneumonia occurred in $5 \%$ of patients [86]. However, brigatinib did not show efficacy for patients harbouring G2032R, the commonest mutation in crizotinib resistance $[12,87]$.

\subsection{Cabozantinib}

The multi-kinase inhibitor cabozantinib, which has demonstrated activity against ALX, KIT, MET, RET, ROS1, VEGFR2 and TIE2 [88], and is already approved for the treatment of medullary thyroid and renal cell carcinoma [89-91], has been administered by Drilon et al. in a phase II study enrolling lung cancer patients [75]. Within the aforementioned clinical trial, a daily dose of $60 \mathrm{mg}$ cabozantinib showed efficacy (in terms of imaging and symptoms) in a young female non-smoker harbouring D2033N-ROS1 genomic alteration who acquired resistance to crizotinib. Additionally, Sun et al. reported clinical efficacy of cabozantinib in four ROS1-positive NSCLC patients with resistance to crizotinib and ceritinib; the PFS of patients administered with cabozantinib ranged from 4.9 to 13.8 months with neutropenia, xeroderma and pulmonary embolism the primary AEs reported [92]. Although cabozantinib has demonstrated its ability to overcome resistance driven by newer identified secondary mutations, it does have a challenging side effect profile.

\subsection{Ceritinib}

Ceritinib, a highly specific and robust ROS1 inhibitor, showed 20 times higher efficacy than crizotinib in a rat model [93], with a satisfactory BBB penetration ratio [94-97]. Ceritinib was approved after a phase II study, which included 32 ROS1-positive NSCLC patients administered with a daily dose of $750 \mathrm{mg}$. Among crizotinib-naïve and crizotinib pretreated patients, the overall ORR was $62 \%$ with a median PFS of 9.3 months. Among 8 patients with CNS disease, $63 \%$ reported disease control, 
while $25 \%$ showed an intracranial response [93]. However, patients receiving ceritinib reported critical rates of toxicities, primarily diarrhoea $(78 \%)$, nausea $(59 \%)$ and anorexia $(56 \%)$ with grade 3 or higher AEs reported by 12 patients (37\%) [93]. Clinical trials investigating different ceritinib combinations to mitigate toxicity are underway. Notably, ceritinib efficacy is restricted to crizotinib-naïve patients; it did not show efficacy towards crizotinib-resistant malignancies [95].

\subsection{Entrectinib}

Entrectinib (ROZLYTREK, Genentech Inc.) is an orally available, low molecular weight TKI, specifically designed to penetrate the BBB. Entrectinib received FDA approval for lung cancers harbouring ROS1 alteration in 2019 [46,47,98], having demonstrated robust ALK and ROS1 inhibition, plus effective TRKA, TRKB and TRKC signalling suppression [99]. However, entrectinib has limited efficacy against G2032R, D2033N and L2026M ROS1 mutants [87,100]. Entrectinib led to a median PFS of 19.0 months and an ORR of 77.4\% within 53 ROS1-positive NSCLC patients recruited for a phase I/II trial [98,101,102]. Among those patients with brain metastasis, the intracranial ORR was 55\% and median PFS of 12.9 months, which makes entrectinib advantageous compared to crizotinib in this cohort; intracranial progression on treatment occurred in three patients (15\%). Entrectinib's overall toxicity was manageable (primarily grade 1 ) and reversible with $27 \%$ and $4 \%$ of patients requiring dose reduction and treatment discontinuation, respectively. Main entrectinib-related toxicities reported were dysgeusia (41\%), fatigue (28\%) and dizziness (25\%) [102].

\subsection{Lorlatinib}

Lorlatinib is a potent oral inhibitor of ALK (FDA approval in 2017) and ROS1 with activity against several ROS1 mutants (G2032R, D2033N and S1986Y), which confer resistance to crizotinib and ceritinib, and the ability to penetrate the BBB [78,103,104]. Promising results have recently been reported by a phase II study that included 47 ROS1-positive NSCLC patients, including both TKI-naïve and pretreated patients [104,105]. A median PFS of 21.0 months and an ORR of $61.5 \%$ were observed among the 13 crizotinib-naïve patients while a median PFS of 8.5 months and an ORR of $26.5 \%$ was reported among the 34 patients pretreated with crizotinib. Surprisingly, an ORR of $66.7 \%$ was observed among the 6 patients with brain metastasis who received no prior treatment [104]. The overall main AEs reported were hypercholesterolemia, hypertriglyceridemia and oedema. Of note, lorlatinib was reported to be efficacious towards resistance mechanisms due to bypass signalling activation, although it showed limited efficacy in patients harbouring G2032R [105].

\subsection{Repotrectinib}

Repotrectinib (TPX-0005) is a low molecular weight, potent TKI with demonstrated efficacy against TRK receptors, ALK and most ROS1 mutants (G2032R, L1951R, S1986F, L2026 and D2033N) with 90 times higher efficacy than crizotinib [106,107]. In June 2017, repotrectinib received FDA orphan drug designation for the treatment of NSCLC harbouring the aforementioned oncogenic mutations. In terms of efficacy, 33 NSCLC patients harbouring ROS1 rearrangements were recruited in a larger phase I study including patients with different solid malignancies and mutations (e.g., TKR and $A L K$ ) and administered with increasing dosage of repotrectinib [108]. While TKI pretreated patients reported an ORR of $39 \%$ with an intracranial response rate of $75 \%$, TKI-naïve patients reported an ORR of $82 \%$ and an intracranial response rate of $100 \%$. Importantly, one patient died following repotrectinib administration, but tumour regression was achieved by five patients who had received prior crizotinib therapy. In terms of toxicity, adverse events were observed for the vast majority of patients, with dizziness (57\%) and dysgeusia (51\%) being the most frequent AEs [108]. The ability to target the ATP-binding site of ROS1 and overcome steric interference created by different mutations meant repotrectinib showed activity against multiple resistance mechanisms, including metastasis, bypass pathways and different mutations. 


\subsection{Other Promising Drugs}

It is worth mentioning additional drugs that are thought to be potentially valuable ROS1 inhibitors. Of these, ensartinib is a low molecular weight, orally available agent currently under evaluation for paediatric ROS1-rearranged patients [109]. Fortinib, although discontinued since 2015, has been shown to be a highly effective ROS1 inhibitor and demonstrated activity against crizotinib-resistant ROS1 mutations [110].

\section{Discussion}

ROS1 inhibitors have demonstrated clinical efficacy against ROS1-rearranged malignancies [75,85,93,102,104,108]. Crizotinib has been a game-changer for the treatment of advanced ROS1-positive lung cancers and it is currently the preferred first-line option for these patients [68]. Unfortunately, the vast majority of patients have reported disease progression and resistance to crizotinib. A new generation of agents capable of ROS1 inhibition is therefore required, mainly for more robust delivery of therapy and penetration of the CNS. Preliminary data from ongoing clinical studies assessing novel inhibitor compounds are very promising, and although ROS1-rearranged cancers are relatively rare, new therapies might provide clinicians with treatment suggestions. Agents including repotrectinib and lorlatinib have demonstrated significant efficacy in the post-crizotinib setting $[104,108]$. The previously mentioned homology with $A L K$-rearranged lung cancers can, moreover, improve understanding of ROS1-driven NSCLC cases under treatment and drive helpful clinical suggestions [111]. Of the numerous strategies employed by cancer cells to evade inhibition, the most studied is point mutation of drug targets, whereby a second mutation event results in resistance to multiple inhibitors [112]. In future, it will be paramount to detect and verify the different resistance mechanisms employed to allow the avoidance of disease progression in lung cancer patients administered with ROS1-targeted therapies [112]. Investigation of bypass signalling pathways, an additional cause of therapy resistance in ROS1 lung cancer, is essential for generation of superior compounds for combination therapies.

On the clinical side, techniques for early stage identification of resistance mechanisms from tissue or blood would facilitate more precise treatment plans with a higher probability of preventing cancer progression and overcoming drug resistance. In this light, it is worth mentioning the first liquid biopsy effort for detection and monitoring of ROS1 circulating tumour DNA (ctDNA) in ROS1-rearranged malignancies $[80,113]$. We hypothesise that a biopsy at the time of disease progression would enable identification and characterisation of drug resistance mechanisms to permit more informed and precise treatment regimens.

\section{Conclusions}

Its inability to penetrate the BBB renders crizotinib unsuitable for ROS1-rearranged NSCLC patients with CNS metastasis; in such cases, entrectinib, ceritinib, repotrectinib and lorlatinib are more appropriate options since these agents were specifically engineered to penetrate the BBB. With that said, although ceritinib and entrectinib are less effective towards crizotinib-resistant malignancies, they showed increased efficacy towards brain metastasis with entrectinib the current preferred and FDA-approved first-line treatment for those with metastatic brain involvement [46] According to the latest results from various clinical trials, repotrectinib and lorlatinib are the most potent ROS1 inhibitors, with good CNS activity and the ability to overcome resistance resulting from bypass signalling activation and alternative ROS1 mutations. Of note, repotrectinib is currently under investigation while lorlatinib has recently been approved for $A L K$-rearranged NSCLC patients and is the current preferred second-line treatment in case of no evidence of G2032R mutation and/or bypass signalling [114]. To summarise, early detection of ROS1-rearranged lung cancers is essential as there are several targeted therapies available, despite the low incidence rate. The understanding of underlying molecular alterations that lead to drug resistance and disease progression, and the 
development of novel drugs to counteract this, is essential for the design of more precise and effective combination therapies.

Funding: This research received no external funding.

Conflicts of Interest: We know of no conflicts of interest associated with this publication.

\section{References}

1. Torre, L.A.; Siegel, R.L.; Ward, E.M.; Jemal, A. Global Cancer Incidence and Mortality Rates and Trends-An Update. Cancer Epidemiol. Biomark. Prev. 2015, 25, 16-27. [CrossRef] [PubMed]

2. Takeuchi, K.; Soda, M.; Togashi, Y.; Suzuki, R.; Sakata, S.; Hatano, S.; Asaka, R.; Hamanaka, W.; Ninomiya, H.; Uehara, H.; et al. RET, ROS1 and ALK Fusions in Lung Cancer. Nat. Med. 2012, 18, 378-381. [CrossRef] [PubMed]

3. Hong, D.S.; Fakih, M.G.; Strickler, J.H.; Desai, J.; Durm, G.A.; Shapiro, G.I.; Falchook, G.S.; Price, T.J.; Sacher, A.; Denlinger, C.S.; et al. KRASG12C Inhibition with Sotorasib in Advanced Solid Tumors. N. Engl. J. Med. 2020, 383, 1207-1217. [CrossRef] [PubMed]

4. Morris, T.A.; Khoo, C.; Solomon, B.J. Targeting ROS1 Rearrangements in Non-small Cell Lung Cancer: Crizotinib and Newer Generation Tyrosine Kinase Inhibitors. Drugs 2019, 79, 1277-1286. [CrossRef] [PubMed]

5. Shaw, A.T.; Ou, S.-H.I.; Bang, Y.-J.; Camidge, D.R.; Solomon, B.J; Salgia, R.; Riely, G.J.; Varella-Garcia, M.; Shapiro, G.I.; Costa, D.B.; et al. Crizotinib in ROS1-Rearranged Non-Small-Cell Lung Cancer. N. Engl. J. Med. 2014, 371, 1963-1971. [CrossRef]

6. Wu, Y.-L.; Yang, J.C.-H.; Kim, D.-W.; Lu, S.; Zhou, J.; Seto, T.; Yang, J.-J.; Yamamoto, N.; Ahn, M.-J.; Takahashi, T.; et al. Phase II Study of Crizotinib in East Asian Patients with ROS1-Positive Advanced Non-Small-Cell Lung Cancer. J. Clin. Oncol. 2018, 36, 1405-1411. [CrossRef] [PubMed]

7. Moro-Sibilot, D.; Cozic, N.; Pérol, M.; Mazières, J.; Otto, J.; Souquet, P.; Bahleda, R.; Wislez, M.; Zalcman, G.; Guibert, S.; et al. Crizotinib in c-MET-or ROS1-Positive NSCLC: Results of the AcSé Phase II Trial. Ann. Oncol. 2019, 30, 1985-1991. [CrossRef]

8. Roys, A.; Chang, X.; Liu, Y.; Xu, X.; Wu, Y.; Zuo, D. Resistance Mechanisms and Potent-Targeted Therapies of ros1-Positive Lung Cancer. Cancer Chemother. Pharmacol. 2019, 84, 679-688. [CrossRef]

9. Genova, C.; Rossi, G.; Tagliamento, M.; Rijavec, E.; Biello, F.; Cerbone, L.; Zullo, L.; Grossi, F. Targeted Therapy of Oncogenic-Driven Advanced Non-Small Cell Lung Cancer: Recent Advances and New Perspectives. Expert Rev. Respir. Med. 2020, 14, 367-383. [CrossRef]

10. Birchmeier, C.; Sharma, S.; Wigler, M. Expression and Rearrangement of the ROS1 Gene in Human Glioblastoma Cells. Proc. Natl. Acad. Sci. USA 1987, 84, 9270-9274. [CrossRef] [PubMed]

11. Roskoski, R. ROS1 Protein-Tyrosine Kinase Inhibitors in the Treatment of ros1 Fusion Protein-Driven Non-Small Cell Lung Cancers. Pharmacol. Res. 2017, 121, 202-212. [CrossRef]

12. Davare, M.A.; Vellore, N.A.; Wagner, J.P.; Eide, C.A.; Goodman, J.R.; Drilon, A.; Deininger, M.W.; O'Hare, T.; Druker, B.J. Structural Insight Into Selectivity and Resistance Profiles of ROS1 Tyrosine Kinase Inhibitors. Proc. Natl. Acad. Sci. USA 2015, 112, E5381-E5390. [CrossRef] [PubMed]

13. Rikova, K.; Guo, A.; Zeng, Q.; Possemato, A.; Yu, J.; Haack, H.; Nardone, J.; Lee, K.; Reeves, C.; Li, Y.; et al. Global Survey of Phosphotyrosine Signaling Identifies Oncogenic Kinases in Lung Cancer. Cell 2007, 131, 1190-1203. [CrossRef] [PubMed]

14. Mazières, J.; Zalcman, G.; Crinò, L.; Biondani, P.; Barlesi, F.; Filleron, T.; Dingemans, A.-M.C.; Léna, H.; Monnet, I.; Rothschild, S.I.; et al. Crizotinib Therapy for Advanced Lung Adenocarcinoma and a ROS1 Rearrangement: Results from the EUROS1 Cohort. J. Clin. Oncol. 2015, 33, 992-999. [CrossRef]

15. Gainor, J.F.; Shaw, A.T. Novel Targets in Non-Small Cell Lung Cancer:ROS1 and RET Fusions. Oncologist 2013, 18, 865-875. [CrossRef]

16. Lin, J.J; Shaw, A.T. Recent Advances in Targeting ROS1 in Lung Cancer. J. Thorac. Oncol. 2017, 12, 1611-1625. [CrossRef] [PubMed]

17. Uguen, A.; De Braekeleer, M. ROS1fusions in Cancer: A Review. Futur. Oncol. 2016, 12, 1911-1928. [CrossRef] 
18. Kudo, M.; Finn, R.S.; Qin, S.; Han, K.-H.; Ikeda, K.; Piscaglia, F.; Baron, A.; Park, J.-W.; Han, G.; Jassem, J.; et al. Lenvatinib Versus Sorafenib in First-Line Treatment of Patients with Unresectable Hepatocellular CarcinomA: A Randomised Phase 3 Non-Inferiority Trial. Lancet 2018, 391, 1163-1173. [CrossRef]

19. Wiesner, T.; He, J.; Yelensky, R.; Esteve-Puig, R.; Botton, T.; Yeh, I.; Lipson, D.; Otto, G.; Brennan, K.; Murali, R.; et al. Kinase Fusions Are Frequent in Spitz Tumours and Spitzoid Melanomas. Nat. Commun. 2014, 5, 1-9. [CrossRef]

20. Liu, Y.; Liu, T.; Li, N.; Wang, T.; Pu, Y.; Lin, R.; Yue, P. Identification of a Novel WNK1-ROS1 Fusion in a Lung Adenocarcinoma Sensitive to Crizotinib. Lung Cancer 2018, 129, 92-94. [CrossRef]

21. Zhang, Y.; Yu, M.; Yuan, M.; Chen, R.; Huang, M. Identification of a Novel RBPMS-ROS1 Fusion in an Adolescent Patient with Microsatellite-instable Advanced Lung Adenocarcinoma Sensitive to Crizotinib: A Case Report. Clin. Lung Cancer 2020, 21, e78-e83. [CrossRef]

22. Shi, E.; Chmielecki, J.; Tang, C.-M.; Wang, K.; Heinrich, M.C.; Kang, G.; Corless, C.L.; Hong, D.; Fero, K.E.; Murphy, J.D.; et al. FGFR1 and NTRK3 Actionable Alterations in "Wild-Type" Gastrointestinal Stromal Tumors. J. Transl. Med. 2016, 14, 339. [CrossRef]

23. Park, S.; Ahn, B.-C.; Lim, S.W.; Sun, J.-M.; Kim, H.R.; Hong, M.H.; Lee, S.-H.; Ahn, J.S.; Park, K.; La Choi, Y.; et al. Characteristics and Outcome of ROS1-Positive Non-Small Cell Lung Cancer Patients in Routine Clinical Practice. J. Thorac. Oncol. 2018, 13, 1373-1382. [CrossRef] [PubMed]

24. Davies, K.D.; Le, A.T.; Theodoro, M.F.; Skokan, M.C.; Aisner, D.L.; Berge, E.M.; Terracciano, L.M.; Cappuzzo, F.; Incarbone, M.; Roncalli, M.; et al. Identifying and Targeting ROS1 Gene Fusions in Non-Small Cell Lung Cancer. Clin. Cancer Res. 2012, 18, 4570-4579. [CrossRef]

25. Gu, T.-L.; Deng, X.; Huang, F.; Tucker, M.; Crosby, K.; Rimkunas, V.; Wang, Y.; Deng, G.; Zhu, L.; Tan, Z.; et al. Survey of Tyrosine Kinase Signaling Reveals ROS Kinase Fusions in Human Cholangiocarcinoma. PLoS ONE 2011, 6, e15640. [CrossRef]

26. Giacomini, C.P.; Sun, S.; Varma, S.; Shain, A.H.; Giacomini, M.M.; Balagtas, J.; Sweeney, R.T.; Lai, E.; Del Vecchio, C.A.; Forster, A.D.; et al. Breakpoint Analysis of Transcriptional and Genomic Profiles Uncovers Novel Gene Fusions Spanning Multiple Human Cancer Types. PLoS Genet. 2013, 9, e1003464. [CrossRef]

27. Birch, A.H.; Arcand, S.L.; Oros, K.K.; Rahimi, K.; Watters, A.K.; Provencher, D.; Greenwood, C.M.; Mes-Masson, A.-M.; Tonin, P.N. Chromosome 3 Anomalies Investigated by Genome Wide SNP Analysis of Benign, Low Malignant Potential and Low Grade Ovarian Serous Tumours. PLoS ONE 2011, 6, e28250. [CrossRef]

28. Lee, J.; Lee, S.E.; Kang, S.Y.; Do, I.G.; Lee, S.; Ha, S.Y.; Cho, J.; Kang, W.K.; Jang, J.; Ou, S.-H.I.; et al. Identification of ROS1rearrangement in Gastric Adenocarcinoma. Cancer 2013, 119, 1627-1635. [CrossRef]

29. Aisner, D.L.; Nguyen, T.T.; Paskulin, D.D.; Le, A.T.; Haney, J.; Schulte, N.; Chionh, F.; Hardingham, J.E.; Mariadason, J.M.; Tebbutt, N.; et al. ROS1 and ALK Fusions in Colorectal Cancer, with Evidence of Intratumoral Heterogeneity for Molecular Drivers. Mol. Cancer Res. 2013, 12, 111-118. [CrossRef]

30. Facchinetti, F.; Rossi, G.; Bria, E.; Soria, J.-C.; Besse, B.; Minari, R.; Friboulet, L.; Tiseo, M. Oncogene Addiction in Non-Small Cell Lung Cancer: Focus on ROS1 Inhibition. Cancer Treat. Rev. 2017, 55, 83-95. [CrossRef]

31. Bergethon, K.; Shaw, A.T.; Ou, S.-H.I.; Katayama, R.; Lovly, C.M.; McDonald, N.T.; Massion, P.P.; Siwak-Tapp, C.; Gonzalez, A.; Fang, R.; et al. ROS1 Rearrangements Define a Unique Molecular Class of Lung Cancers. J. Clin. Oncol. 2012, 30, 863-870. [CrossRef]

32. Lin, J.J.; Ritterhouse, L.L.; Ali, S.M.; Bailey, M.; Schrock, A.B.; Gainor, J.F.; Ferris, L.A.; Mino-Kenudson, M.; Miller, V.A.; Iafrate, A.J.; et al. ROS1 Fusions Rarely Overlap with Other Oncogenic Drivers in Non-Small Cell Lung Cancer. J. Thorac. Oncol. 2017, 12, 872-877. [CrossRef]

33. Lin, J.J.; Langenbucher, A.; Gupta, P.; Yoda, S.; Fetter, I.J.; Rooney, M.; Do, A.; Kem, M.; Chang, K.P.; Oh, A.Y.; et al. Small Cell Transformation of ROS1 Fusion-Positive Lung Cancer Resistant to ROS1 Inhibition. NPJ Precis. Oncol. 2020, 4, 1-8. [CrossRef]

34. Wiesweg, M.; Eberhardt, W.E.; Reis, H.; Ting, S.; Savvidou, N.; Skiba, C.; Herold, T.; Christoph, D.C.; Meiler, J.; Worm, K.; et al. High Prevalence of Concomitant Oncogene Mutations in Prospectively Identified Patients with ROS1-Positive Metastatic Lung Cancer. J. Thorac. Oncol. 2017, 12, 54-64. [CrossRef]

35. Chen, Y.-F.; Hsieh, M.-S.; Wu, S.-G.; Chang, Y.-L.; Yu, C.-J.; Yang, J.C.-H.; Yang, P.-C.; Shih, J.-Y. Efficacy of Pemetrexed-Based Chemotherapy in Patients with ROS1 Fusion-Positive Lung Adenocarcinoma Compared with in Patients Harboring Other Driver Mutations in East Asian Populations. J. Thorac. Oncol. 2016, 11, 1140-1152. [CrossRef] 
36. Scheffler, M.; Schultheis, A.; Teixido, C.; Michels, S.; Morales-Espinosa, D.; Viteri, S.; Hartmann, W.; Merkelbach-Bruse, S.; Fischer, R.; Schildhaus, H.-U.; et al. ROS1 Rearrangements in Lung AdenocarcinomA: Prognostic Impact, Therapeutic Options and Genetic Variability. Oncotarget 2015, 6, 10577-10585. [CrossRef]

37. Liang, Y.; Wakelee, H.A.; Neal, J.W. Relationship of Driver Oncogenes to Long-Term Pemetrexed Response in Non-Small-Cell Lung Cancer. Clin. Lung Cancer 2014, 16, 366-373. [CrossRef]

38. Riess, J.; Padda, S.K.; Bangs, C.D.; Das, M.; Neal, J.W.; Adrouny, A.R.; Cherry, A.; Wakelee, H.A. A Case Series of Lengthy Progression-Free Survival With Pemetrexed-Containing Therapy in Metastatic Non-Small-Cell Lung Cancer Patients Harboring ROS1 Gene Rearrangements. Clin. Lung Cancer 2013, 14, 592-595. [CrossRef]

39. Song, Z.; Su, H.; Zhang, Y. Patients with ROS 1 Rearrangement-Positive Non-Small-Cell Lung Cancer Benefit From Pemetrexed-Based Chemotherapy. Cancer Med. 2016, 5, 2688-2693. [CrossRef]

40. Zhang, L.; Jiang, T.; Zhao, C.; Li, W.; Li, X.; Zhao, S.; Liu, X.; Jia, Y.; Yang, H.; Ren, S.; et al. Efficacy of Crizotinib and Pemetrexed-Based Chemotherapy in Chinese NSCLC Patients with ROS1 Rearrangement. Oncotarget 2016, 7, 75145-75154. [CrossRef] [PubMed]

41. Lee, J.-O.; Kim, T.M.; Lee, S.-H.; Kim, D.-W.; Kim, S.; Jeon, Y.K.; Chung, D.H.; Kim, W.H.; Kim, Y.W.; Yang, S.-C.; et al. Anaplastic Lymphoma Kinase Translocation: A Predictive Biomarker of Pemetrexed in Patients with Non-small Cell Lung Cancer. J. Thorac. Oncol. 2011, 6, 1474-1480. [CrossRef]

42. Ren, S.; Chen, X.; Kuang, P.; Zheng, L.; Su, C.; Li, J.; Li, B.; Wang, Y.; Liu, L.; Hu, Q.; et al. Association of EGFR Mutation or ALK Rearrangement with Expression of DNA Repair and Synthesis Genes in Never-Smoker Women with Pulmonary Adenocarcinoma. Cancer 2012, 118, 5588-5594. [CrossRef]

43. Mazieres, J.; Drilon, A.; Lusque, A.; Mhanna, L.; Cortot, A.; Mezquita, L.; Thai, A.; Mascaux, C.; Couraud, S.; Veillon, R.; et al. Immune Checkpoint Inhibitors for Patients with Advanced Lung Cancer and Oncogenic Driver Alterations: Results from the IMMUNOTARGET Registry. Ann. Oncol. 2019, 30, 1321-1328. [CrossRef]

44. Patil, T.; Smith, D.E.; Bunn, P.A.; Aisner, D.L.; Le, A.T.; Hancock, M.; Purcell, W.T.; Bowles, D.W.; Camidge, D.R.; Doebele, R.C. The Incidence of Brain Metastases in Stage IV ROS1-Rearranged Non-Small Cell Lung Cancer and Rate of Central Nervous System Progression on Crizotinib. J. Thorac. Oncol. 2018, 13, 1717-1726. [CrossRef]

45. Gainor, J.F.; Tseng, D.; Yoda, S.; Dagogo-Jack, I.; Friboulet, L.; Lin, J.J.; Hubbeling, H.G.; Dardaei, L.; Farago, A.F.; Schultz, K.R.; et al. Patterns of Metastatic Spread and Mechanisms of Resistance to Crizotinib in ROS1-Positive Non-Small-Cell Lung Cancer. JCO Precis. Oncol. 2017, 1, 1-13. [CrossRef]

46. Sehgal, K.; Piper-Vallillo, A.J.; Viray, H.; Khan, A.M.; Rangachari, D.; Costa, D.B. Cases of ROS1-Rearranged Lung Cancer: When to Use Crizotinib, Entrectinib, Lorlatinib, and Beyond? Precis. Cancer Med. 2020, 3, 17. [CrossRef]

47. Lee, J.; Park, S.; Jung, H.A.; Sun, J.-M.; Lee, S.-H.; Ahn, J.S.; Park, K.; Ahn, M.-J. Evaluating Entrectinib as a Treatment Option for Non-Small Cell Lung Cancer. Expert Opin. Pharmacother. 2020, 1-8. [CrossRef]

48. Metro, G.; Lunardi, G.; Floridi, P.; Pascali, J.P.; Marcomigni, L.; Chiari, R.; Ludovini, V.; Crinò, L.; Gori, S. CSF Concentration of Crizotinib in Two ALK-Positive Non-Small-Cell Lung Cancer Patients with CNS Metastases Deriving Clinical Benefit from Treatment. J. Thorac. Oncol. 2015, 10, e26-e27. [CrossRef]

49. Lukas, R.V.; Hasan, Y.; Nicholas, M.K.; Salgia, R. ROS1 Rearranged Non-Small Cell Lung Cancer Brain Metastases Respond to Low Dose Radiotherapy. J. Clin. Neurosci. 2015, 22, 1978-1979. [CrossRef]

50. Bubendorf, L.; Büttner, R.; Al-Dayel, F.; Dietel, M.; Elmberger, G.; Kerr, K.; López-Ríos, F.; Marchetti, A.; Öz, B.; Pauwels, P.; et al. Testing for ROS1 in Non-Small Cell Lung Cancer: A Review with Recommendations. Virchows Archiv. 2016, 469, 489-503. [CrossRef]

51. Kocher, M.; Soffietti, R.; Abacioglu, U.M.; Villà, S.; Fauchon, F.; Baumert, B.G.; Fariselli, L.; Tzuk-Shina, T.; Kortmann, R.-D.; Carrie, C.; et al. Adjuvant Whole-Brain Radiotherapy Versus Observation After Radiosurgery or Surgical Resection of One to Three Cerebral Metastases: Results of the EORTC 22952-26001 Study. J. Clin. Oncol. 2011, 29, 134-141. [CrossRef]

52. Andrews, D.W.; Scott, C.B.; Sperduto, P.W.; Flanders, A.E.; Gaspar, L.E.; Schell, M.C.; Werner-Wasik, M.; Demas, W.; Ryu, J.; Bahary, J.-P.; et al. Whole Brain Radiation Therapy with or Without Stereotactic Radiosurgery Boost for Patients with One to Three Brain Metastases: Phase III Results of the RTOG 9508 Randomised Trial. Lancet 2004, 363, 1665-1672. [CrossRef] 
53. Lindeman, N.I.; Cagle, P.T.; Aisner, D.L.; Arcila, M.E.; Beasley, M.B.; Bernicker, E.H.; Colasacco, C.; Dacic, S.; Hirsch, F.R.; Kerr, K.; et al. Updated Molecular Testing Guideline for the Selection of Lung Cancer Patients for Treatment With Targeted Tyrosine Kinase Inhibitors: Guideline From the College of American Pathologists, the International Association for the Study of Lung Cancer, and the Association for Molecular Pathology. Arch. Pathol. Lab. Med. 2018, 142, 321-346. [CrossRef]

54. Rogers, T.-M.; Russell, P.A.; Wright, G.; Wainer, Z.; Pang, J.-M.; Henricksen, L.A.; Singh, S.; Stanislaw, S.; Grille, J.; Roberts, E.; et al. Comparison of Methods in the Detection of ALK and ROS1 Rearrangements in Lung Cancer. J. Thorac. Oncol. 2015, 10, 611-618. [CrossRef]

55. Bozzetti, C.; Nizzoli, R.; Tiseo, M.; Squadrilli, A.; Lagrasta, C.; Buti, S.; Gasparro, D.; Zanoni, D.; Majori, M.; De Filippo, M.; et al. ALK and ROS1 Rearrangements Tested by Fluorescence in Situ Hybridization in Cytological Smears From Advanced Non-Small Cell Lung Cancer Patients. Diagn. Cytopathol. 2015, 43, 941-946. [CrossRef] [PubMed]

56. Mescam-Mancini, L.; Lantuéjoul, S.; Moro-Sibilot, D.; Rouquette, I.; Souquet, P.-J.; Audigier-Valette, C.; Sabourin, J.-C.; Decroisette, C.; Sakhri, L.; Brambilla, E.; et al. On the Relevance of a Testing Algorithm for the Detection of ROS1-Rearranged Lung Adenocarcinomas. Lung Cancer 2014, 83, 168-173. [CrossRef]

57. Boyle, T.A.; Masago, K.; Ellison, K.E.; Yatabe, Y.; Hirsch, F.R. ROS1 Immunohistochemistry Among Major Genotypes of Non-Small-Cell Lung Cancer. Clin. Lung Cancer 2014, 16, 106-111. [CrossRef] [PubMed]

58. Rogers, T.-M.; Arnau, G.M.; Ryland, G.L.; Huang, S.; Lira, M.E.; Emmanuel, Y.; Perez, O.D.; Irwin, D.; Fellowes, A.P.; Wong, S.Q.; et al. Multiplexed Transcriptome Analysis to Detect ALK, ROS1 and RET Rearrangements in Lung Cancer. Sci. Rep. 2017, 7, 42259. [CrossRef]

59. Shan, L.; Lian, F.; Guo, L.; Qiu, T.; Ling, Y.; Ying, J.; Lin, D. Detection of ROS1 Gene Rearrangement in Lung Adenocarcinoma: Comparison of IHC, FISH and Real-Time RT-PCR. PLoS ONE 2015, 10, e0120422. [CrossRef] [PubMed]

60. Sholl, L.M.; Sun, H.; Butaney, M.; Zhang, C.; Lee, C.; Jänne, P.A.; Rodig, S.J. ROS1 Immunohistochemistry for Detection of ROS1-Rearranged Lung Adenocarcinomas. Am. J. Surg. Pathol. 2013, 37, 1441-1449. [CrossRef]

61. Wong, S.Q.; Li, J.; Tan, A.Y.-C.; Vedururu, R.; Pang, J.-M.B.; Do, H.; Ellul, J.; Doig, K.; Bell, A.; McArthur, G.A.; et al. Sequence Artefacts in a Prospective Series of Formalin-Fixed Tumours Tested for Mutations in Hotspot Regions by Massively Parallel Sequencing. BMC Med. Genom. 2014, 7, 23. [CrossRef]

62. Zheng, Z.; Liebers, M.; Zhelyazkova, B.; Cao, Y.; Panditi, D.; Lynch, K.D.; Chen, J.; Robinson, H.E.; Shim, H.S.; Chmielecki, J.; et al. Anchored Multiplex PCR for Targeted Next-Generation Sequencing. Nat. Med. 2014, 20, 1479-1484. [CrossRef]

63. Davies, K.D.; Le, A.T.; Sheren, J.; Nijmeh, H.; Gowan, K.; Jones, K.L.; Varella-Garcia, M.; Aisner, D.L.; Doebele, R.C. Comparison of Molecular Testing Modalities for Detection of ROS1 Rearrangements in a Cohort of Positive Patient Samples. J. Thorac. Oncol. 2018, 13, 1474-1482. [CrossRef]

64. Benayed, R.; Offin, M.; Mullaney, K.; Sukhadia, P.; Rios, K.; Desmeules, P.; Ptashkin, R.; Won, H.; Chang, J.; Halpenny, D.; et al. High Yield of RNA Sequencing for Targetable Kinase Fusions in Lung Adenocarcinomas with No Mitogenic Driver Alteration Detected by DNA Sequencing and Low Tumor Mutation Burden. Clin. Cancer Res. 2019, 25, 4712-4722. [CrossRef]

65. Yasuda, H.; De Figueiredo-Pontes, L.L.; Kobayashi, S.; Costa, D.B. Preclinical Rationale for Use of the Clinically Available Multitargeted Tyrosine Kinase Inhibitor Crizotinib in ROS1-Translocated Lung Cancer. J. Thorac. Oncol. 2012, 7, 1086-1090. [CrossRef]

66. Bos, M.; Gardizi, M.; Schildhaus, H.-U.; Heukamp, L.; Geist, T.; Kaminsky, B.; Zander, T.; Nogova, L.; Scheffler, M.; Dietlein, M.; et al. Complete Metabolic Response in a Patient with Repeatedly Relapsed Non-Small Cell Lung Cancer Harboring ROS1 Gene Rearrangement After Treatment with Crizotinib. Lung Cancer 2013, 81, 142-143. [CrossRef] [PubMed]

67. Chiari, R.; Buttitta, F.; Iacono, D.; Bennati, C.; Metro, G.; Di Lorito, A.; Iezzi, M.; Tiseo, M.; Mazzoni, F.; Cappuzzo, F.; et al. Dramatic Response to Crizotinib in ROS1 Fluorescent In Situ Hybridization-and Immunohistochemistry-Positive Lung Adenocarcinoma: A Case Series. Clin. Lung Cancer 2014, 15, 470-474. [CrossRef]

68. Shaw, A.; Riely, G.; Bang, Y.-J.; Kim, D.-W.; Camidge, D.; Solomon, B.; Varella-Garcia, M.; Iafrate, A.; Shapiro, G.; Usari, T.; et al. Crizotinib in ROS1-Rearranged Advanced Non-Small-Cell Lung Cancer (NSCLC): Updated Results, Including Overall Survival, from PROFILE 1001. Ann. Oncol. 2019, 30, 1121-1126. [CrossRef] [PubMed] 
69. FDA. FDA Expands Use of Xalkori to Treat Rare Form of Advanced Non-Small Cell Lung Cancer. Available online: https://www.fda.gov/news-events/press-announcements/fda-expands-use-xalkori-treat-rare-formadvanced-non-small-cell-lung-cancer (accessed on 16 September 2020).

70. Moro-Sibilot, D.; Faivre, L.; Zalcman, G.; Pérol, M.; Barlesi, F.; Otto, J.; Monnet, I.; Cortot, A.B.; Wislez, M.; Lena, H.; et al. Crizotinib in Patients with Advanced ROS1-Rearranged Non-Small Cell Lung Cancer (NSCLC). Preliminary Results of the ACSé Phase II Trial. J. Clin. Oncol. 2015, 33, 8065. [CrossRef]

71. Michels, S.; Massutí, B.; Schildhaus, H.-U.; Franklin, J.; Sebastian, M.; Felip, E.; Grohé, C.; Rodriguez-Abreu, D.; Abdulla, D.S.; Bischoff, H.; et al. Safety and Efficacy of Crizotinib in Patients with Advanced or Metastatic ROS1-Rearranged Lung Cancer (EUCROSS): A European Phase II Clinical Trial. J. Thorac. Oncol. 2019, 14, 1266-1276. [CrossRef]

72. Dziadziuszko, R.; Le, A.T.; Wrona, A.; Jassem, J.; Camidge, D.R.; Varella-Garcia, M.; Aisner, D.L.; Doebele, R.C. An Activating KIT Mutation Induces Crizotinib Resistance in ROS1-Positive Lung Cancer. J. Thorac. Oncol. 2016, 11, 1273-1281. [CrossRef]

73. McCoach, C.E.; Le, A.T.; Gowan, K.; Jones, K.; Schubert, L.; Doak, A.; Estrada-Bernal, A.; Davies, K.D.; Merrick, D.T.; Bunn, P.A.; et al. Resistance Mechanisms to Targeted Therapies in ROS1p and ALKp Non-Small Cell Lung Cancer. Clin. Cancer Res. 2018, 24, 3334-3347. [CrossRef] [PubMed]

74. Facchinetti, F.; Loriot, Y.; Cassin-Kuo, M.-S.; Mahjoubi, L.; Lacroix, L.; Planchard, D.; Besse, B.; Farace, F.; Auger, N.; Remon, J.; et al. Crizotinib-Resistant ROS1 Mutations Reveal a Predictive Kinase Inhibitor Sensitivity Model for ROS1-and ALK-Rearranged Lung Cancers. Clin. Cancer Res. 2016, 22, 5983-5991. [CrossRef]

75. Drilon, A.; Somwar, R.; Wagner, J.P.; Vellore, N.A.; Eide, C.A.; Zabriskie, M.S.; Arcila, M.E.; Hechtman, J.F.; Wang, L.; Smith, R.S.; et al. A Novel Crizotinib-Resistant Solvent-Front Mutation Responsive to Cabozantinib Therapy in a Patient with ROS1-Rearranged Lung Cancer. Clin. Cancer Res. 2016, 22, 2351-2358. [CrossRef]

76. Awad, M.M.; Katayama, R.; McTigue, M.; Liu, W.; Deng, Y.-L.; Brooun, A.; Friboulet, L.; Huang, D.; Falk, M.D.; Timofeevski, S.; et al. Acquired Resistance to Crizotinib from a Mutation in CD74-ROS1. N. Engl. J. Med. 2013, 368, 2395-2401. [CrossRef]

77. Gainor, J.F.; Friboulet, L.; Yoda, S.; Alghalandis, L.D.; Farago, A.F.; Logan, J.; Schultz, K.; Sequist, L.V.; Engelman, J.A.; Shaw, A.T. Frequency and Spectrum of ROS1 Resistance Mutations in ROS1-Positive Lung Cancer Patients Progressing on Crizotinib. J. Clin. Oncol. 2016, 34, 9072. [CrossRef]

78. Zou, H.Y.; Li, Q.; Engstrom, L.D.; West, M.; Appleman, V.; Wong, K.A.; McTigue, M.; Deng, Y.L.; Liu, W.; Brooun, A.; et al. PF-06463922 is a Potent and Selective Next-Generation ROS1/ALK Inhibitor Capable of Blocking Crizotinib-Resistant ROS1 Mutations. Proc. Natl. Acad. Sci. USA 2015, 112, 3493-3498. [CrossRef]

79. Song, A.; Kim, T.M.; Kim, D.-W.; Kim, S.; Keam, B.; Lee, S.-H.; Heo, D.S. Molecular Changes Associated with Acquired Resistance to Crizotinib in ROS1-Rearranged Non-Small Cell Lung Cancer. Clin. Cancer Res. 2015, 21, 2379-2387. [CrossRef]

80. Dagogo-Jack, I.; Rooney, M.; Nagy, R.J.; Lin, J.J.; Chin, E.; Ferris, L.A.; Ackil, J.; Lennerz, J.K.; Lanman, R.B.; Gainor, J.F.; et al. Molecular Analysis of Plasma from Patients with ROS1-Positive NSCLC. J. Thorac. Oncol. 2019, 14, 816-824. [CrossRef]

81. Katayama, R.; Shaw, A.T.; Khan, T.M.; Mino-Kenudson, M.; Solomon, B.J.; Halmos, B.; Jessop, N.A.; Wain, J.C.; Yeo, A.T.; Benes, C.; et al. Mechanisms of Acquired Crizotinib Resistance in ALK-Rearranged Lung Cancers. Sci. Transl. Med. 2012, 4, 120ra17. [CrossRef]

82. Sasaki, T.; Koivunen, J.; Ogino, A.; Yanagita, M.; Nikiforow, S.; Zheng, W.; Lathan, C.; Marcoux, J.P.; Du, J.; Okuda, K.; et al. A Novel ALK Secondary Mutation and EGFR Signaling Cause Resistance to ALK Kinase Inhibitors. Cancer Res. 2011, 71, 6051-6060. [CrossRef]

83. Doebele, R.C.; Pilling, A.B.; Aisner, D.L.; Kutateladze, T.G.; Le, A.T.; Weickhardt, A.J.; Kondo, K.L.; Linderman, D.J.; Heasley, L.E.; Franklin, W.A.; et al. Mechanisms of Resistance to Crizotinib in Patients with ALK Gene Rearranged Non-Small Cell Lung Cancer. Clin. Cancer Res. 2012, 18, 1472-1482. [CrossRef]

84. Markham, A. Brigatinib: First Global Approval. Drugs 2017, 77, 1131-1135. [CrossRef] [PubMed]

85. Camidge, D.R.; Kim, H.R.; Ahn, M.-J.; Yang, J.C.; Han, J.-Y.; Lee, J.S.; Hochmair, M.; Li, J.Y.-C.; Chang, G.-C.; Lee, K.H.; et al. Brigatinib versus Crizotinib in ALK-Positive Non-Small-Cell Lung Cancer. N. Engl. J. Med. 2018, 379, 2027-2039. [CrossRef] 
86. Gettinger, S.N.; Bazhenova, L.A.; Langer, C.J.; Salgia, R.; Gold, K.A.; Rosell, R.; Shaw, A.T.; Weiss, G.J.; Tugnait, M.; Narasimhan, N.I.; et al. Activity and Safety of Brigatinib in Alk-Rearranged Non-Small-Cell Lung Cancer and Other Malignancies: A Single-Arm, Open-Label, Phase 1/2 Trial. Lancet Oncol. 2016, 17, 1683-1696. [CrossRef]

87. Chong, C.R.; Bahcall, M.; Capelletti, M.; Kosaka, T.; Ercan, D.; Sim, T.; Sholl, L.M.; Nishino, M.; Johnson, B.E.; Gray, N.S.; et al. Identification of Existing Drugs That Effectively Target NTRK1 and ROS1 Rearrangements in Lung Cancer. Clin. Cancer Res. 2016, 23, 204-213. [CrossRef]

88. D'Angelo, A.; Sobhani, N.; Bagby, S.; Casadei-Gardini, A.; Roviello, G. Cabozantinib as a Second-Line Treatment Option in Hepatocellular Carcinoma. Expert Rev. Clin. Pharmacol. 2020, 13, 1-7. [CrossRef]

89. D'Angelo, A.; Bagby, S.; Di Pierro, G.; Chirra, M.; Nobili, S.; Mini, E.; Villari, D.; Roviello, G. An Overview of the Clinical Use of Cabozantinib in the Treatment of Advanced Non-Clear-Cell Renal Cell Carcinoma (NCCRCC). Crit. Rev. Oncol. 2020, 149, 102921. [CrossRef]

90. Elisei, R.; Schlumberger, M.J.; Müller, S.P.; Schöffski, P.; Brose, M.S.; Shah, M.H.; Licitra, L.; Jarzab, B.; Medvedev, V.; Kreissl, M.C.; et al. Cabozantinib in Progressive Medullary Thyroid Cancer. J. Clin. Oncol. 2013, 31, 3639-3646. [CrossRef]

91. Choueiri, T.K.; Escudier, B.; Powles, T.; Mainwaring, P.N.; Rini, B.I.; Donskov, F.; Hammers, H.J.; Hutson, T.E.; Lee, J.-L.; Peltola, K.; et al. Cabozantinib versus Everolimus in Advanced Renal-Cell Carcinoma. N. Engl. J. Med. 2015, 373, 1814-1823. [CrossRef]

92. Sun, T.Y.; Niu, X.; Chakraborty, A.; Neal, J.W.; Wakelee, H. Lengthy Progression-Free Survival and Intracranial Activity of Cabozantinib in Patients with Crizotinib and Ceritinib-Resistant ROS1-Positive Non-Small Cell Lung Cancer. J. Thorac. Oncol. 2019, 14, e21-e24. [CrossRef]

93. Lim, S.M.; Kim, H.R.; Lee, J.S.; Lee, K.H.; Lee, Y.-G.; Min, Y.J.; Cho, E.K.; Lee, S.S.; Kim, B.-S.; Choi, M.Y.; et al. Open-Label, Multicenter, Phase II Study of Ceritinib in Patients with Non-Small-Cell Lung Cancer Harboring ROS1 Rearrangement. J. Clin. Oncol. 2017, 35, 2613-2618. [CrossRef] [PubMed]

94. Crinò, L.; Ahn, M.-J.; De Marinis, F.; Groen, H.J.M.; Wakelee, H.; Hida, T.; Mok, T.; Spigel, D.; Felip, E.; Nishio, M.; et al. Multicenter Phase II Study of Whole-Body and Intracranial Activity with Ceritinib in Patients with ALK-Rearranged Non-Small-Cell Lung Cancer Previously Treated with Chemotherapy and Crizotinib: Results From ASCEND-2. J. Clin. Oncol. 2016, 34, 2866-2873. [CrossRef]

95. Dagogo-Jack, I.; Shaw, A.T. Expanding the Roster of ROS1 Inhibitors. J. Clin. Oncol. 2017, 35, $2595-2597$. [CrossRef]

96. Facchinetti, F.; Tiseo, M.; Di Maio, M.; Graziano, P.; Bria, E.; Rossi, G.; Novello, S. Tackling ALK in Non-Small Cell Lung Cancer: The Role of Novel Inhibitors. Transl. Lung Cancer Res. 2016, 5, 301-321. [CrossRef]

97. Muller, I.B.; De Langen, A.J.; Honeywell, R.J.; Giovannetti, E.; Peters, G.J. Overcoming Crizotinib Resistance in ALK-Rearranged NSCLC with the Second-Generation ALK-Inhibitor Ceritinib. Expert Rev. Anticancer. Ther. 2016, 16, 147-157. [CrossRef]

98. Facchinetti, F.; Friboulet, L. Profile of Entrectinib and Its Potential in the Treatment of ROS1-Positive NSCLC: Evidence to Date. Lung Cancer 2019, 10, 87-94. [CrossRef]

99. Ardini, E.; Menichincheri, M.; Banfi, P.; Bosotti, R.; De Ponti, C.; Pulci, R.; Ballinari, D.; Ciomei, M.; Texido, G.; Degrassi, A.; et al. Entrectinib, a Pan-TRK, ROS1, and ALK Inhibitor with Activity in Multiple Molecularly Defined Cancer Indications. Mol. Cancer Ther. 2016, 15, 628-639. [CrossRef]

100. Liu, D.; Offin, M.; Harnicar, S.; Li, B.T.; Drilon, A. Entrectinib: An Orally Available, Selective Tyrosine Kinase Inhibitor for the Treatment of NTRK, ROS1, and ALK Fusion-Positive Solid Tumors. Ther. Clin. Risk Manag. 2018, 14, 1247-1252. [CrossRef] [PubMed]

101. Drilon, A.; Siena, S.; Ou, S.H.I.; Patel, M.; Ahn, M.J.; Lee, J.; Bauer, T.M.; Farago, A.F.; Wheler, J.J.; Liu, S.V.; et al. Safety and Antitumor Activity of the Multitargeted Pan-TRK, ROS1, and ALK Inhibitor Entrectinib: Combined Results from Two Phase I Trials (ALKA-372-001 and STARTRK-1). Cancer Discov. 2017, 7, 400-409. [CrossRef]

102. Drilon, A.; Siena, S.; Dziadziuszko, R.; Barlesi, F.; Krebs, M.G.; Shaw, A.T.; De Braud, F.; Rolfo, C.; Ahn, M.-J.; Wolf, J.; et al. Entrectinib in ROS1 Fusion-Positive Non-Small-Cell Lung Cancer: Integrated Analysis of Three Phase 1-2 Trials. Lancet Oncol. 2020, 21, 261-270. [CrossRef] 
103. Pfizer's Next-Generation ALK/ROS1 Inhibitor, Lorlatinib, Granted Breakthrough Therapy Designation from FDA for ALK-Positive Metastatic Non-Small Cell Lung Cancer, Pfizer. Available online: https://www.pfizer.com/news/press-release/press-release/detail/pfizer_s_next_generation_alk_ros1_ inhibitor_lorlatinib_granted_breakthrough_therapy_designation_from_fda_for_alk_positive_metastatic_ non_small_cell_lung_cancer (accessed on 17 September 2020).

104. Shaw, A.T.; Solomon, B.J.; Chiari, R.; Riely, G.J.; Besse, B.; Soo, R.A.; Kao, S.; Lin, C.-C.; Bauer, T.M.; Clancy, J.S.; et al. Lorlatinib in Advanced ROS1-Positive Non-Small-Cell Lung Cancer: A Multicentre, Open-Label, Single-Arm, Phase 1-2 Trial. Lancet Oncol. 2019, 20, 1691-1701. [CrossRef]

105. Solomon, B.J.; Besse, B.; Bauer, T.M.; Felip, E.; Soo, R.A.; Camidge, D.R.; Chiari, R.; Bearz, A.; Lin, C.-C.; Gadgeel, S.M.; et al. Lorlatinib in Patients with ALK-Positive Non-Small-Cell Lung Cancer: Results from a Global Phase 2 Study. Lancet Oncol. 2018, 19, 1654-1667. [CrossRef]

106. Drilon, A.; Ou, S.H.I.; Cho, B.C.; Kim, D.W.; Lee, J.; Lin, J.J.; Zhu, V.W.; Ahn, M.J.; Camidge, D.R.; Nguyen, J.; et al. Repotrectinib (Tpx-0005) is a Next-Generation ros1/Trk/Alk Inhibitor That Potently Inhibits ROS1/TRK/ALK Solvent-Front Mutations. Cancer Discov. 2018, 8, 1227-1236. [CrossRef] [PubMed]

107. Cui, J.; Zhai, D.; Deng, W.; Rogers, E.; Huang, Z.; Whitten, J.; Li, Y. TPX-0005, a Novel ALK/ROS1/TRK Inhibitor, Effectively Inhibited a Broad Spectrum of Mutations Including Solvent Front ALK G1202R, ROS1 G2032R and TRKA G595R Mutants. Eur. J. Cancer 2016, 69, S32. [CrossRef]

108. Cho, B.C.; Drilon, A.E.; Doebele, R.C.; Kim, D.-W.; Lin, J.J.; Lee, J.; Ahn, M.-J.; Zhu, V.W.; Ejadi, S.; Camidge, D.R.; et al. Safety and Preliminary Clinical Activity of Repotrectinib in Patients with Advanced ROS1 Fusion-Positive Non-Small Cell Lung Cancer (TRIDENT-1 Study). J. Clin. Oncol. 2019, 37, 9011. [CrossRef]

109. Lovly, C.M.; Heuckmann, J.M.; De Stanchina, E.; Chen, H.; Thomas, R.K.; Liang, C.; Pao, W. Insights into ALK-Driven Cancers Revealed through Development of Novel ALK Tyrosine Kinase Inhibitors. Cancer Res. 2011, 71, 4920-4931. [CrossRef]

110. Davare, M.A.; Saborowski, A.; Eide, C.A.; Tognon, C.; Smith, R.L.; Elferich, J.; Agarwal, A.; Tyner, J.W.; Shinde, U.P.; Lowe, S.W.; et al. Foretinib Is a Potent Inhibitor of Oncogenic ROS1 Fusion Proteins. Proc. Natl. Acad. Sci. USA 2013, 110, 19519-19524. [CrossRef]

111. Shaw, A.T.; Friboulet, L.; Leshchiner, I.; Gainor, J.F.; Bergqvist, S.; Brooun, A.; Burke, B.J.; Deng, Y.-L.; Liu, W.; Dardaei, L.; et al. Resensitization to Crizotinib by the Lorlatinib ALK Resistance Mutation L1198F. N. Engl. J. Med. 2016, 374, 54-61. [CrossRef]

112. McCoach, C.E.; Bivona, T.G.; Blakely, C.M.; Doebele, R.C. Neoadjuvant Oncogene-Targeted Therapy in Early Stage Non-Small-Cell Lung Cancer as a Strategy to Improve Clinical Outcome and Identify Early Mechanisms of Resistance. Clin. Lung Cancer 2016, 17, 466-469. [CrossRef] [PubMed]

113. Huang, W.-L.; Chen, Y.-L.; Yang, S.-C.; Ho, C.-L.; Wei, F.; Wong, D.T.; Su, W.-C.; Lin, C.-C. Liquid Biopsy Genotyping in Lung Cancer: Ready for Clinical Utility? Oncotarget 2017, 8, 18590-18608. [CrossRef]

114. Killock, D. Lorlatinib in ROS1-Positive NSCLC. Nat. Rev. Clin. Oncol. 2020, 17, 7. [CrossRef]

Publisher's Note: MDPI stays neutral with regard to jurisdictional claims in published maps and institutional affiliations.

(C) 2020 by the authors. Licensee MDPI, Basel, Switzerland. This article is an open access article distributed under the terms and conditions of the Creative Commons Attribution (CC BY) license (http://creativecommons.org/licenses/by/4.0/). 